\title{
PERAN KONSELING CLIENT CENTERED DALAM MENINGKATKAN KEPERCAYAAN DIRI SISWA
}

\author{
Kusuma Ratih Nur Chasanah, Awik Hidayati, Aldila Fitri Radite Nur Maynawati Program Studi \\ Bimbingan dan Konseling, Fakultas Keguruan dan Ilmu Pendidikan, \\ Universitas Veteran Bangun Nusantara Sukoharjo \\ Email: kratih420@gmail.com
}

\begin{tabular}{|c|c|}
\hline Article Info & ABSTRAK \\
\hline $\begin{array}{l}\text { Available } \\
\text { online } \\
15.06 .2020\end{array}$ & $\begin{array}{l}\text { Di dalam studi kepustakaan ini mempunyai tujuan untuk mendeskripsikan tentang } \\
\text { peran konseling client centered dalam meningkatkan kepercayaan diri siswa. Metode yang } \\
\text { digunakan dalam penelitian ini ialah Studi Kepustakaan. Hasil dari studi pustaka ini adalah } \\
\text { 1) Keberhasilan penerapan peran konseling client centered dalam meningkatkan } \\
\text { kepercayaan diri bahwa pendekatan client centered sangat efektif untuk meningkatkan } \\
\text { kepercayaan diri siswa. 2) Pengaplikasian pendekatan client centered dapat dilaksanakan } \\
\text { dengan konseling individu dan konseling kelompok serta bimbingan kelompok dengan } \\
\text { pemberian tugas tertentu yang bertujuan untuk memudahkan dalam membantu } \\
\text { menyelesaikan masalah siswa/klien. 3) Sasaran atau penerapan konseling client centered } \\
\text { ialah pada siswa SMP, SMA dan SMK.Bagi guru BK supaya terus mengeksplorasi dirinya } \\
\text { dalam menggunakan pendekatan-pendekatan konseling saat melakukan layanan Bimbingan } \\
\text { dan Konseling serta mengintensifkan pemberian layanan konseling dengan pendekatan client } \\
\text { centered terutama dalam mengatasi masalah kepercayaan diri rendah yang dihadapi klien. } \\
\text { Kata kunci: Konseling Client Centered, Kepercayaan Diri Siswa. }\end{array}$ \\
\hline
\end{tabular}

\section{PENDAHULUAN}

Hakikatnya manusia adalah makhluk yang sempurna karena telah memiliki akal yang dapat dipergunakan untuk berpikir. Manusia diberi oleh Tuhan pikiran yang berguna untuk mengembangkan potensi dalam dirinya, sehingga menjadi manusia yang kreatif, unik dan bermanfaat bagi dirinya sendiri dan orang lain. Setiap manusia juga mempunyai hak untuk mempunyai cita-cita yang tinggi, mempunyai impian serta kesuksesan di masa depannya. Dalam meraih itu semua diperlukan kegigihan, kekuatan, perjuangan yang kuat dan kepercayaan diri tinggi.

Manusia juga mempunyai hak yang melekat pada dirinya sejak lahir yang disebut HAM (Hak Asasi Manusia). Oleh adanya HAM, manusia bebas untuk mengeksplorasi dirinya, mengekspresikan perasaanya dan mengambil keputusan secara mandiri ketika ada masalah 
yang menghampiri dirinya. Masalah yang sering dihadapi siswa sekarang yaitu siswa bisa memantau keseharian seseorang hanya lewat medsosnya. Lambat laun, jika siswa terlalu bergantung pada medsos ini, akan mulai membandingkan diri dengan orang lain, hanya lebih suka berada di zona nyaman takut mengeksplorasi potensi diri, siswa disuruh maju ke depan kelas tidak mau. Apalagi berbicara di depan kelas seperti pada waktu presentasi, hal itu percaya diri sangat rendah dan lambat laun dapat hilang (Radar Jawa Pos, 2019). Permasalahan lain yang dihadapi siswa SMK yaitu saat penulis di tugaskan melaksanakan PPL pada bulan September sampai bulan Oktober 2019 dalam menghadapi dunia perindustrian siswa sangat kurang percaya diri, masih sangat membutuhkan bimbingan tetapi dalam kenyataan Guru BK tidak menghiraukan masalah tersebut. Padahal percaya diri sangat dibutuhkan dalam menghadapi dunia kerja setelah lulus. Berkaitan dengan hal itu Bimbingan dan Konseling selalu beriringan dengan manusia untuk membantu dalam pemecahan masalah secara efektif dan efisien. Salah satu pendekatan yang ada dalam Bimbingan dan Konseling yaitu pendekatan client centered.

Menurut Willis (2014:63) Client Centered Therapy sering juga disebut Psikoterapi NonDirective adalah suatu metode perawatan psikis yang dilakukan dengan cara berdialog antara konselor dengan klien, agar tercapai gambaran yang serasi antara ideal self (diri klien yang ideal) dengan actual self (diri klien sesuai dengan kenyataan sebenarnya). Pendekatan ini juga mengatakan bahwa seseorang yang mempunyai masalah pada dasarnya tetap memiliki potensi dan mampu mengatasi masalahnya sendiri.

Menurut Prayitno dan Erman Amti (2014:64) client centered theraphy adalah klien diberi kesempatan mengemukakan persoalan, perasaan dan pikiran- pikirannya secara bebas. Pendekatan ini juga mengatakan bahwa seseorang yang mempunyai masalah pada dasarnya tetap memiliki potensi dan mampu mengatasi masalahnya sendiri. Jadi client centered therapy adalah terapi yang berpusat pada diri client, yang mana seorang konselor hanya memberikan terapi serta mengawasi klien pada saat mendapatkan pemberian terapi tersebut agar klien dapat berkembang atau keluar dari masalah yang dihadapinya atau disebut juga dengan konselor hanya sebagai fasilitator. 
Pendekatan person centered therapy dikembangkan oleh Carl Ranson Rogers pada awal tahun 1940-an. Pada awalnya, konseling yang berkembang pada saat itu menggunakan nama konseling nondirektif (nondirective counseling) yang dikembangkan oleh para ahli psikologi perilaku dan psikologi analitis. Rogers berusaha untuk membantah bahwa konselor adalah orang yang tahu segalanya. Menurutnya konseli adalah orang yang mampu mengarahkan dirinya sendiri. Pada tahun 1942, setelah berpraktek konseling individual, Rogers kemudian mengembangkan suatu yang sistematis mengenai kepribadian manusia. Selanjutnya teori yang telah dikembangkannya diaplikasikanya dalam praktek sehari-hari. Teori ini kemudian ia beri nama pendekatan atau terapi yang berpusat pada konseli (client centered aproach). Pendekatan ini memandang bahwa semua manusia adalah unik dan mempunyai kemampuan untuk meraih sesuatu dengan segala potensi yang dimilikinya. Kemampuan serta potensi ini dimiliki oleh setiap manusia dan selalu diharapkan untuk dapat dicapai. Rogers juga memandang bahwa manusia mempunyai kecenderungan untuk dapat mengaktualisasikan dirinya serta dapat mengarahkan dirinya sendiri.

Terkait halnya dengan percaya diri. Menurut Hakim (2002:63) Rasa percaya diri dapat diartikan suatu keyakinan seseorang terhadap segala aspek kelebihan yang dimilikinya dan keyakinan tersebut membuatnya merasa mampu untuk bisa mencapai berbagai tujuan dalam hidupnya. Menurut Muhajir (2013:35) self-confidence merupakan personal judgment bahwa ia mampu melaksanakan tugas dengan baik. Dapat disimpulkan bahwa percaya diri merupakan yakin pada diri dan memastikan pada dirinya bahwa ia mampu untuk melaksanakan tugas dengan baik serta mampu mencapai tujuan hidup.

Oleh karena itu konseling Client Centered yang berpusat pada diri seseorang untuk memecahkan masalah yang dihadapinya merupakan suatu pendekatan yang tepat untuk meningkatkan kepercayaan diri siswa pada era globalisasi seperti sekarang ini. Karena dalam menggunakan pendekatan client centered konselor merupakan orang yang dipercaya oleh klien sehingga tercipta kenyamanan pada klien untuk menceritakan permasalahan yang ada sampai klien dapat menyelesaikan permasalahannya secara mandiri dan tepat.

\section{METODE PENELITIAN}

Metode yang digunakan dalam penulisan makalah ini ialah Studi Kepustakaan. Menurut Hermawan (2019:18) Studi Kepustakaan adalah segala usaha yang dilakukan peneliti untuk menghimpun informasi yang relevan dengan topik atau masalah yang akan atau sedang diteliti. 
Informasi itu dapat diperoleh dari buku-buku ilmiah, laporan penelitian, karangan-karangan ilmiah, tesis dan disertasi, peraturan- peraturan, ketetapan-ketetapan, buku tahunan, ensiklopedia, dan sumber-sumber tertulis baik cetak maupun elektronik.

\section{PEMBAHASAN}

Percaya diri siswa dapat ditingkatkan menggunakan konseling client centered. Karena dalam menggunakan konseling client centered penyelesaian masalah berfokus pada diri klien serta keputusan akan diambil oleh klien secara mandiri. Selain itu menggunakan konseling client centered sangat efektif dan efisisen untuk memecahkan masalah yang dihadapi siswa. Dari jurnal yang telah dirangkai perihal tentang peran client centered dalam meningkatkan kepercayaan diri siswa. Keberhasilan penggunaan konseling client centered dalam meningkatkan kepercayaan diri siswa tersebut yang pertama ialah pemaparan dari jurnal penelitian yang dilakukan oleh Siti Komariyah, Lathifah dan Nuryanto (2019) dengan judul Efektivitas Layanan Konseling Kelompok dengan Pendekatan Client Centered untuk Meningkatkan Kepercayaan Diri Pada Siswa Kelas VIII SMP N 16 Yogyakarta Tahun Ajaran 2018/2019 hasil penelitiannya dapat disimpulkan bahwa layanan konseling kelompok menggunakan pendekatan client centered efektif dalam upaya meningkatkan kepercayaan diri siswa. Post test menghasilkan bahwa siswa kelas VIII SMP N 16 Yogyakarta Tahun Ajaran 2018/2019 tingkat kepercayaan dirinya tergolong sedang. Setelah pemberian konseling kelompok menggunakan pendekatan client centered kepercayaan diri siswa meningkat 10,87\%. Diperoleh hasil rata-rata angket variabel kepercayaan diri tiap aspek sebelum dan sesudah diberikan treatment meningkat. Dilihat dari aspek fleksibel mendapatkan nilai meningkat sebelum diberikan treatment diperoleh angka sebesar 15,11 dan sesudah diberikan treatment diperoleh angka sebesar 23,33. Aspek Bertoleransi sebelum diberikan treatment diperoleh angka sebesar 13,44 dan sesudah treatment diperoleh angka sebesar 22,67. Aspek Kemampuan keyakinan diri sebelum diberikan treatment diperoleh angka sebesar 13,29 meningkat sesudah diberikan treatment diperoleh angka sebesar 20,43. Aspek Optimis sebelum diberikan treatment diperoleh angka sebesar 12,14 dan meningkat sesudah diberikan treatment diperoleh angka sebesar 16. Aspek Objektif diperoleh angka sebelum diberikan treatment sebesar 11,43 dan sesudah diberikan treatment diperoleh angka sebesar 15,14. Aspek Bertanggung jawab diperoleh angka sebelum diberikan treatment sebesar 12,75 
meningkat sesudah diberikan treatment diperoleh angka sebesar 20,50. Aspek Rasional dan realistis diperoleh angka sebelum diberikan treatment sebesar 13,14 dan sesudah diberikan treatment diperoleh angka sebesar 21,29. Berdasarkan hasil sebelum dan sesudah treatment dengan diberikannya layanan konseling kelompok pendekatan client centered diperoleh peningkatkan aspek kepercayaan diri tertinggi yaitu aspek bertoleransi yaitu dari 13,44 meningkat 22,67.

Berdasarkan rata-rata kepercayaan diri siswa secara keseluruhan yang diperoleh sebelum diberikan treatment sebesar 101,28 dan sesudah diberikan treatment diperoleh angka sebesar 155,42. Dari hasil tersebut siswa dituntut untuk memiliki kepercayaan diri secara optimal agar mereka menjadi individu yang mampu bersosialisasi dengan baik kepada seluruh kalangan baik yang muda maupun yang tua. Siswa juga harus memilki pemikiran rasional dan realistis atau bisa menerima kenyataan apa yang telah terjadi pada diri mereka. Siswa juga dituntut untuk menjadi individu yang bertanggung jawab, karena menumbuhkan rasa tanggung jawab pada siswa sejak dini, itu untuk melatihkan mereka menjadi sosok individu yang beribawa dan mentaati norma dan nilai yang berlaku di masyarakat. Siswa harus menanamkan rasa tanggung jawab pada diri masing-masing, adapun tanggung jawab siswa sebagai pelajar adalah belajar dengan baik, mengerjakan tugas sekolah yang sudah diberikan, dan disiplin menjalani tata tertib di sekolah. Jadi dengan diberikannya layanan konseling kelompok pendekatan client centered adalah agar siswa mampu mengatur atau mengarahkan perilakunya agar berkembang perasaan, pikiran, persepsi, wawasan, sikap kemampuan untuk berkomunikasi dan bersosialisasi dengan memiliki pengelolaan diri yang baik. Maka penelitian yang dilakukan dinyatakan berhasil.

Lalu jurnal penelitian yang dilakukan oleh Archimedes Gerry, Syahriman dan Arsyadani Mishbahuluddin (2019) berjudul Pengaruh Layanan Konseling Kelompok Pendekatan Client Centered Terhadap Kepercayaan Diri Siswa Kelas VIII E di SMP Negeri 7 Kota Bengkulu hasil penelitian yang dilakukan bahwa ada pengaruh yang signifikan layanan konseling kelompok pendekatan client centered terhadap kepercayaan diri siswa kelas VIII E di SMP Negeri 7 Kota Bengkulu. Dibuktikan dengan hasil analisis dari subjek yaitu ada peningkatan kepercayaan diri siswa sebesar 66,27\% dengan melakukan treatment sebanyak empat kali pertemuan konseling kelompok pendekatan client centered karena menurut peneliti dalam jurnal, pertemuan empat kali tersebut dapat menciptakan suasana nyaman, sehingga anggota 
konseling kelompok dapat mengemukakan permasalahan yang dihadapinya. Kepercayaan diri dapat ditumbuhkan melalui berbagai macam cara, salah satunya adalah melalui layanan konseling kelompok pendekatan client centered, karena dalam konseling kelompok pendekatan client centered siswa dituntut untuk aktif mengemukakan pendapatnya dari diri mereka sendiri. Selain dapat menumbuhkan percaya diri, dalam konseling kelompok pendekatan client centered juga siswa diajarkan untuk saling menghargai pendapat, kreativitas dalam mencari solusi, memperluas wawasan, memberikan pelajaran mengenai pengembangan diri, kesadaran diri, serta pemahaman terhadap diri sendiri, dan terbentuk dinamika konseling kelompok pendekatan client centered bagi para anggota kelompok.

Selanjutnya berdasarkan hasil penelitian yang dilakukan Sri Dwi Anggraeni (2016) yang berjudul Pengaruh Konseling Kelompok Dengan Pendekatan Person Centered Terhadap Rasa percaya Diri Siswa Kelas VII SMP Muhammadiyah 2 Kota Kediri, bahwa ada pengaruh konseling kelompok dengan pendekatan person centered terhadap rasa percaya diri siswa kelas VII SMP Muhammadiyah 2 Kota Kediri Tahun Ajaran 2016/2017. Berdasarkan penelitian ini, direkomendasikan bagi konselor atau guru bimbingan dan konseling di sekolah dapat menerapkan layanan konseling kelompok dengan pendekatan person centered untuk membantu siswa yang memiliki rasa percaya diri yang rendah agar peserta didik dapat berkembang dan mampu meningkatkan kemampuan dan potensinya. Dalam penelitian ini siswa mampu mengutarakan pendapatnya di depan umum, rasa minder hilang sedikit demi sedikit dan kekhawatiran akan kesalahan, menjadi kesalahan merupakan hal yang biasa untuk menjadikan pribadi yang lebih baik.

Penelitian yang dilakukan Lestari, Rini Larassati \& Laily Puji Astuti (2017) berjudul Peningkatan Percaya Diri Siswa Menggunakan Layanan Bimbingan Kelompok Melalui Pendekatan Person Centered berdasarkan hasil penelitian bahwa terdapat peningkatan percaya diri siswa setelah penggunaan layanan bimbingan kelompok melalui pendekatan person centered. Dengan hasil post test rasa percaya diri meningkat 22,5\% dengan 10 subjek penelitian diberikan layanan bimbingan kelompok sebanyak 3 pertemuan dengan jenis kelompok tugas dan dalam setiap pertemuan diberi tema khusus untuk meningkatkan percaya diri siswa SMK Penerbangan Bandar Lampung. Bimbingan kelompok melatih siswa untuk berani berbicara atau mengungkapkan pendapat dan perasaannya, melatih siswa berani tampil di depan banyak orang, melatih siswa untuk saling ber-tenggang rasa, melatih untuk 
saling menghormati, melatih untuk menanggapi pendapat orang lain, melatih untuk berinteraksi dan berkomunikasi dengan penuh rasa percaya diri. Suasana kelompok yang diciptakan dalam bimbingan kelompok lama kelamaan akan mempengaruhi sikap dan tingkah laku siswa sehingga siswa akan mengikuti apa saja yang dilakukan teman-temannya dalam kelompok.

Berdasarkan hasil penelitian Susi Susanti (2018) yang berjudul Pengaruh Konseling Pendekatan Client Centered Terhadap Peningkatan Kepercayaan Diri Siswa Kelas XI Di SMKN 1 Solok bahwa konseling pendekatan client centered dalam meningkatkan kepercayaan diri siswa menunjukan trend peningkatan kepercayaan diri siswa yang mulanya rendah setelah diberikan konseling pendekatan client centered sebanyak enam kali karena penelitian ini menggunakan format individual, dimana tahapan-tahapannya adalah sebagai berikut: 1) Pengantaran 2) Penjajakan, 3) penafsiran, 4) pembinaan dengan pendekatan clien centered, 5) penilaian. Ada 4 siswa sebagai subjek untuk malaksanakan treatment, dalam pertemuan terakhir siswa sudah tidak lagi memerlukan bantuan untuk menceritakan permasalahan percaya diri mereka, maka kepercayaan diri siswa menjadi baik. Artinya kepercayaan diri siswa kelas XI di SMK N 1 Solok meningkat dengan diberikan layanan konseling client centered.

Berdasarkan hasil penelitian Yulia Paramitha (2019) dengan judul Pengaruh Pendekatan Client Centered Terhadap Kepercayaan Diri Siswa Kelas VIII-1 Di SMP Negeri 7 Kisaran bahwa pemberian pendekatan client centered pada siswa yang memiliki kepercayaan diri rendah memberikan pengaruh pada siswa kelas VIII-1 di SMP Negeri 7 Kisaran. Dalam pemberian treatment dilakukan empat tahapan dan untuk melihat hasil dari kepercayaan diri siswa, maka pada saat tes akhir/ posttest terdapat 30 butir soal dalam bentuk pilihan ganda yaitu soal mengenai kepercayaan diri siswa. 30 butir soal tersebut terlebih dahulu disesuikan dengan tujuh indikator kepercayaan diri. Adapun tujuh indikator tersebut kemauan dan usaha, optimis, mandiri, tidak mudah menyerah, memiliki dan memanfaatkan kelebihan, memiliki mental dan fisik yang menunjang. Adapun jumlah siswa yang memiliki kategori kepercayaan diri sedang sebanyak 1 orang sebesar 25\%, dan siswa yang memiliki kategori kepercayaan diri sangat tinggi sebanyak 3 orang sebesar 75\%. Maka dari itu penelitian tersebut berhasil dilakukan.

Sedangkan hasil penelitian Diza Rahma Azzahra, Rizna Nur Septyanti \& Wiwin Yuliani (2019) yang berjudul Pengaruh Client-Centered Therapy Dalam Meningkatkan Kepercayaan 
Diri Siswa SMA bahwa pendekatan melalui konseling client centered dapat membantu individu mengembangkan potensinya seperti dalam meningkatkan kepercayaan diri konseli, sehingga dalam hal tersebut dapat dilihat adanya pengaruh pendekatan konseling client-centered terhadap meningkatnya rasa kepercayaan diri konseli.

Dari kajian jurnal di atas bahwa dari hasil penelitian yang telah dilakukan pendekatan client centered dapat meningkatkan kepercayaan diri siswa dengan penelitian yang sudah dilakukan. Baik dengan layanan konseling individu, konseling kelompok maupun dengan bimbingan kelompok, masalah percaya diri siswa SMP, SMA dan SMK dapat teratasi dengan efektif dan signifikan dengan menggunakan konseling client centered.

Berdasarkan kajian jurnal di atas, maka dapat disimpulkan bahwa pendekatan client centered sangat efektif untuk meningkatkan kepercayaan diri siswa. Oleh karena itu guru BK atau Konselor perlu menerapkan pendekatan client centered untuk meningkatkan kepercayaan diri siswa karena pendekatan client centered berfokus pada diri seseorang dan masalah yang dihadapinya akan diselesaikan secara mandiri. Sesuai dengan pendapat Willis (2014:63) Pendekatan Client Centered Therapy ini mengatakan bahwa seseorang yang mempunyai masalah pada dasarnya tetap memiliki potensi dan mampu mengatasi masalahnya sendiri.

Selain itu konseling client centered dapat dikembangkan atau diaplikasikan dengan layanan konseling yang lain. Berdasarkan pemaparan jurnal di atas layanan yang dapat digunakan yaitu konseling individu dan konseling kelompok. Dan percaya diri dapat ditingkatkan melalui pendekatan client centered layanan bimbingan kelompok menggunakan pemberian tugas bertema khusus. Maka Guru BK atau Konselor dapat mengembangkan pendekatan client centered dengan tepat berdasarkan permasalahan yang dihadapi siswa.

Penulis juga menemukan beberapa point yang dapat digunakan sebagai referensi tambahan untuk calon Guru BK, Guru BK atau Konselor antara lain ialah konseling client centered dapat mengatasi rendahnya percaya diri siswa dengan beberapa kali pemberian treatment dengan tahapan 1) Pengantaran 2) Penjajakan, 3) penafsiran, 4) pembinaan dengan pendekatan clien centered,5) penilaian. Sehingga di akhir treatment menghasilkan siswa mampu datang sendiri kepada konselor tanpa paksaan. Sependapat dengan teori yang dikemukakan oleh Willis (2017:101) dalam tahapan-tahapan konseling client centered, Klien datang kepada konselor atas kemauan sendiri. Apabila klien datang atas suruhan orang lain, 
maka konselor harus mampu menciptakan situasi yang sangat bebas dan permisif dengan tujuan agar klien memilih apakah ia akan terus meminta bantuan atau akan membatalkannya.

Kemudian pendekatan client centered dapat dikembangkan menggunakan bimbingan kelompok dengan pemberian tugas tema tertentu dengan tujuan dalam bimbingan kelompok dapat melatih siswa untuk berani berbicara atau mengungkapkan pendapat dan perasaannya, melatih siswa berani tampil di depan banyak orang, melatih siswa untuk saling ber-tenggang rasa, melatih untuk saling menghormati, melatih untuk me-nanggapi pendapat orang lain, melatih untuk berinteraksi dan berkomunikasi dengan penuh rasa percaya diri. Suasana kelompok yang diciptakan dalam bimbingan kelompok lama kelamaan akan mempengaruhi sikap dan tingkah laku siswa sehingga siswa akan mengikuti apa saja yang dilakukan temantemannya dalam kelompok. Beriringan dengan pendapat Willis (2017:101) Klien menentukan pilihan sikap dan tindakan yang akan diambil (perencanaan) dan klien merealisasikan pilihannya itu.

Dalam konseling client centered konselor dapat melakukan treatment empat kali, enam kali atau lebih karena semakin banyak pertemuan maka rasa nyaman dan aman akan mucul secara alamiah kepada diri klien. Sehingga potensi yang dimiliki klien akan tereksplorasi dan klien mudah dalam mengatasi masalah secara mandiri. Didukung dengan pendapat Paramitha dalam Rosada (2016:6) Pendekatan dalam konseling Rogers berkisar antara lain pada caracara penerimaan pernyataan dan komunikasi, menghargai orang lain, dan memahami klien. Karena itu dalam teknik amat diutamakan sifat-sifat konselor yaitu 1) Acceptence artinya konselor menerima klien sebagaimana adanya dengan segala masalahnya, 2) Congruence artinya karakteristik konselor adalah terpadu, sesuai kata dengan perbuatan, konsisten, 3) Understanding artinya konselor harus dapat secara akurat dan memahami secara empati dunia klien sebagaimana dilihat dari dalam klien itu, 4) Nonjudgemental artinya tidak member penilaian terhadap klien, akan tetapi konselor selalu objektif.

\section{PENUTUP}

\section{Kesimpulan}

Berdasarkan dari hasil penelitian studi kepustakaan penulis dapat menarik kesimpulan untuk menjawab rumusan masalah bahwa Pendekatan client centered yang telah dijadikan review penulis, memberikan bukti dari hasil penelitian yang telah dilakukan dalam jurnal 
bahwa pendekatan client centered efektif dan signifikan apabila digunakan untuk meningkatkan kepercayaan diri siswa.

Pengaplikasian pendekatan client centered dapat dilaksanakan dengan konseling individu dan konseling kelompok serta bimbingan kelompok dengan pemberian tugas tema tertentu yang bertujuan untuk memudahkan dalam membantu menyelesaikan masalah siswa/klien.

Dalam konseling client centered konselor dapat melakukan treatment empat kali, enam kali atau lebih karena semakin banyak pertemuan maka rasa nyaman dan aman akan mucul secara alamiah kepada diri klien. Sehingga potensi yang dimiliki klien akan tereksplorasi dan klien mudah dalam mengatasi masalah secara mandiri.

\section{Saran}

Berdasarkan pembahasan dan kesimpulan di atas penulis mengajukan saran yaitu 1) Bagi Guru BK supaya terus mengeksplorasi dirinya dalam menggunakan pendekatan saat melakukan layanan Bimbingan dan Konseling serta mengintensifkan pemberian layanan konseling dengan pendekatan client centered terutama dalam mengatasi masalah kepercayaan diri rendah yang dihadapi klien, 2) Bagi peneliti selanjutnya supaya lebih mencermati, memahami dan menerapkan dimana pendekatan client centered tepat untuk digunakan.

\section{DAFTAR PUSTAKA}

Amti, Erman dan Prayitno. 2014. Dasar-Dasar Bimbingan dan Konseling. Jakarta: PT. Renika Cipta.

Anggraeni, Sri, D. 2017. Pengaruh Konseling Kelompok Dengan Pendekatan Person Centered Terhadap Rasa percaya Diri Siswa Kelas VII SMP Muhammadiyah 2 Kota Kediri. File Article.pdf. Diunduh di http://simki.unpkediri.ac.id/mahasiswa/file artikel/ pada $3 / 5 / 2020$

Archimedes, G., Syahriman, \& Arsyadani, M. 2019. Pengaruh Layanan Konseling Kelompok Pendekatan Client Centered Terhadap Kepercayaan Diri Siswa Kelas VIII E di SMP Negeri 7 Kota Bengkulu. Consilia. Vol 2 (2). Diunduh di http://garuda.ristekbrin.go.id/documents/detail/1225508 pada 2/5/2020

Azzahra, Diza, R, Rizna, N, S, Wiwin, Y. 2019. Pengaruh Client-Centered Therapy Dalam Meningkatkan Kepercayaan Diri Siswa SMA. Fokus (Kajian Bimbingan dan Konseling 
Dalam Pendidikan). Vol.2(1). Diunduh di https://journal.ikipsiliwangi.ac.id/index.php/fokus/article/ pada 10/5/2020.

Bandura, A. 1997. Self-Efficacy. New York: Academic Press.

Ghufron \& Rini. 2011. Teori-teori Psikologi. Yogyakarta: AR-RUZZ MEDIA Hakim, Thursan. 2002. Mengatasi Rasa Tidak Percaya Diri. Jakarta: Puspa Swara.

Hermawaan, Iwan. 2019. Teknik Menulis Karya Ilmiah Berbasis Aplikasi Dan Metodologi.

Karawang : Hidayatul Quran.

Komariyah, S., \& Nuryanto, I. L. 2019. Efektifitas Layanan Konseling Kelompok dengan Pendekatan Client Centered Untuk Meningkatkan Kepercayaan Diri Pada Siswa KelasVIII SMP N 16 Yogyakarta Tahun Ajaran 2018/2019. G-Couns: Jurnal Bimbingan dan Konseling, 4(1). Diunduh di https://journal.upy.ac.id/index.php/bk/article/ pada 2/5/2020 jam 23.11 WIB

Lestari, Rini, L, \& Laily, P, A. 2017. Peningkatan Percaya Diri Siswa Menggunakan Layanan Bimbingan Kelompok Melalui Pendekatan Person Centered. Prosiding Seminar Bimbingan dan Konseling. Vol. 1, No.1,2017, hlm.238-247. Diunduh di http://pasca.um.ac.id/conferences/index.php/snbk pada 18/4/ 2020

Muhajir.Noeng. 2013. psikologi positif. Jakarta. Rake Sarasin

Muthia. Sayekti. 2018. Berdamai Dengan Diri Sendiri. Yogyakarta : Psikologi Corner Paramitha, Y. 2019. Pengaruh Pendekatan Clien Centered Terhadap Kepercayaan Diri Siswa $\begin{array}{lllllll}\text { Kelas VIII-1 di } & \text { SMP } & \text { Negeri } & 7 & \text { Kisaran. Diunduh di }\end{array}$ http://repository.uinsu.ac.id/6827/1/YULIA\%20PARAMITHA.pdf pada 9/5/2020

Sarjiyati. 2019. Membangun Percaya Diri Dalam Diri Siswa. Kudus: Radar Jawa Pos.

Susanti, S. 2018. Pengaruh Konseling Pendekatan Client Centered Terhadap Peningkatan Kepercayaan Diri Siswa Kelas XI Di SMKN 1 Solok. Diunduh di http://repo.iainbatusangkar.ac.id/xmlui/handle/123456789/12060 pada 7/5/2020 Willis, Sofyan S., Konseling Individual Teori dan Praktek, Bandung : Alfabeta, 2004 